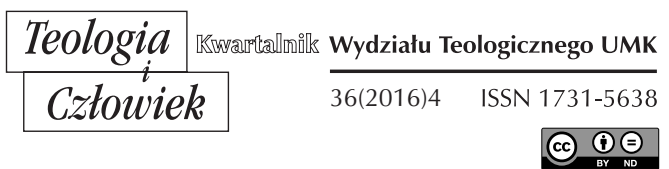

KS. ZDZISŁAW PAWŁOWSKI*

TORUŃ-WŁOCŁAWEK

\title{
KONIEC HISTORII JAKO PERSPEKTYWA HERMENEUTYCZNA \\ W KSIĘGACH KRÓLEWSKICH
}

DOI: http://dx.doi.org/10.12775/TiCz.2016.045

Harold Bloom w przedmowie do znanej książki Zakhor. Jewish History and Jewish Memory autorstwa Yosefa Yerushalmi przywołuje innego żydowskiego myśliciela, Leo Straussa, który zwraca uwagę na epikurejskie pojmowanie historii: „Epikur nie interesuje się smutkami przeszłości. Wspomina przeszłość tylko w takim stopniu, w jakim dostarcza przyjemności. Decydującą cechą Epikurejczyka jest to, że jest on niezdolny do przyjęcia cierpienia, wyłaniającego się z jego przeszłości”" ${ }^{1}$. Bloom w komentarzu do tego stwierdzenia dodaje, że nic nie jest bardziej antyżydowskie niż takie właśnie rozumienie dziejów. Dlatego wskazuje na Yosefa Yerushalmi jako przykładowego historyka żydowskiego, który swoją pracą odsłania problematyczne i prawdopodobnie niedające się

* Ks. Zdzisław Pawłowski jest wykładowcą egzegezy Starego i Nowego Testamentu oraz teologii biblijnej na Wydziale Teologicznym UMK w Toruniu (zdziwpaw@umk.pl).

${ }^{1}$ Foreword, w: Y.H. Yerushalmi, Zakhor. Jewish History and Jewish Memory, Seatle 1982, 1996, s. XIII. 
pogodzić rozdarcie między żydowską pamięcią a żydowską historiografią ${ }^{2}$. Sam Yerushalmi, omawiając podstawy biblijnej historii i pamięci, zgadza się z tym, aby Herodota nazywać 'ojcem historii', ponieważ wraz z innymi wielkimi historykami Grecji i Rzymu położył fundamenty pod pisarstwo historyczne jakie znamy dzisiaj. Tym niemniej, ani on, ani żaden inny grecki czy rzymski dziejopisarz nie poszukiwał ostatecznego lub transcendentnego znaczenia w historii. Dlatego przekonuje, że ojcami całościowego sensu historii są Żydzi. Oczywiście to wyjątkowe podejście do przeszłości ma swoje źródło w Biblii Hebrajskiej, zwłaszcza tej jej części, która należy do zbioru Proroków Wcześniejszych (Joz - 1 i 2 Krl). Zawarte w nim narracje historyczne, choć na pierwszy rzut oka opisują wydarzenia z przeszłości, to jednak nie pasują do grecko-rzymskiego kanonu pisarstwa historycznego. Treść niektórych przenika ton tragiczny, co sprawia, że ich lekturze towarzyszy bardziej przygnębienie niż przyjemność ${ }^{3}$.

Yerushalmi wyraża pogląd, że biblijne zainteresowanie historią kończy się zasadniczo na Księgach Królewskich, a dokładniej, na zwieńczającym je opisie zniszczenia Jerozolimy przez Babilończyków i deportacji jej mieszkańców do Babilonu4. Dzisiejsza egzegeza nie dostrzega w tym wydarzeniu końca historii, który powoduje nie tylko zerwanie ciągłości w łańcuchu wydarzeń historycznych, ale domaga się nowego sposobu ich interpretacji. Przypisuje mu ona tę samą rangę co zdarzeniom poprzedzającym, łącząc je z nimi w nieprzerwany ciąg chronologiczny. Tymczasem sens tragiczny historii daje się wydobyć i opisać jedynie w hermeneutyce nieciągłości, która czyni wyłom w szeregu jednorodnych zdarzeń i nadaje mu radykalną inność, sytuując go jakby 'poza' historią.

Księgi Królewskie opisują koniec historii z perspektywy jednostkowej egzystencji, dla której śmierć stanowi absolutny kres. Podejmują one próbę interpretacji ciągłości dziejów z wnętrza nieciągłości, przeżywanej w osobistych losach jednostek, w pytaniu o ostateczny sens ich osobowej tożsamości. Nieciągłość pojawia się już w sytuacjach najgłębszych egzystencjalnych potrzeb. Pytanie o tożsamość w takim kontekście zakłada

2 Tamże, XIV.

${ }^{3}$ Por. Ch. Exum, Tragedy and Biblical Narrative: Arrows of the Almighty, Cambridge 1996, s. 1nn.

${ }^{4}$ Y.H. Yerushalmi, Zakhor, s. $14 \mathrm{n}$. 
przerwę między potrzebą a jej spełnieniem. Otwierająca się wówczas szczelina może stać się źródłem nie rozpoznanych jeszcze znaczeń, zakreślających zręby hermeneutyki końca. Według tego kryterium można w Księgach Królewskich wyodrębnić opowiadania, które wydobywają na światło dzienne zdarzenia, stawiające ludzi w horyzoncie zerwania historycznej ciągłości z ich dotychczasową tożsamością jednostkową i zbiorową. Znajdujemy je w epizodach, mających cechy sytuacji granicznych, których filozoficzną definicję podaje Karl Jaspers: „W odniesieniu do naszego bytu empirycznego są one ostateczne. Nie da się ich przeniknąć poznawczo; empirycznie nie widzimy już poza nimi nic innego. Są jak mur, o który uderzamy, o który się rozbijamy. Nie potrafimy ich zmienić, lecz jedynie naświetlić, nie mogąc ich wywieść i wyjaśnić przez odniesienie do czegoś innego" ${ }^{5}$.

Oczywiście, Księgi Królewskie nie przedstawiają sytuacji granicznych za pomocą języka filozoficznego. Pokazują je w opowieściach, które opisują klęskę głodu, warunki życia w oblężonym mieście i wydarzenia związane $\mathrm{z}$ wojną.

Skupiają się one wokół postaci Eliasza i Elizeusza, których historie tworzą cykl prorocki, usytuowany w centrum (1 Krl $17-2 \mathrm{Krl} 9)$. Ale ich zapowiedź znajduje się już na początku, w modlitwie Salomona z okazji poświęcenia świątyni (1 Krl 8,31-51). Wreszcie swoją najpełniejszą artykulację otrzymują $\mathrm{w}$ finalnym, relatywnie obszernym zwieńczeniu (2 Krl 24-25). Graniczne doświadczenie końca przenika zatem całą strukturę Ksiąg Królewskich w kluczowych momentach fabuły: na początku, w środku i w zakończeniu. Zapowiedź stanowi ich antycypację, rzucającą cień na cały początek (1 Krl 1-11). Opowieści w rozległym centrum definiują koniec w środku historii (1 Krl 17-2 Krl 13), a quasi-historyczny dokument opisuje jego nadejście w narracyjnym domknięciu (2 Krl 17-25). Te różne formy obecności końca w zwrotnych punktach struktury literackiej nie są bez wpływu na wymowę całego dzieła i interpretację jego poszczególnych części. Wybrane epizody zawierają narracyjny opis końca i stanowią rodzaj soczewki, przez którą należy czytać całość dzieła.

${ }^{5}$ K. Jaspers, Sytuacje graniczne, tłum. A Staniewska, M. Skwieciński, w: Jaspers, red. R. Rudziński, Warszawa 1978, s. 188. 


\section{KONIEC W MODLITWIE SALOMONA 1 KRL 8,31-51}

Ta część modlitwy wymienia siedem próśb zanoszonych do Boga Izraela, przedstawiających swego rodzaju typologię sytuacji granicznych, które będzie przeżywał lud Izraela ${ }^{6}$. Odnoszą się one najpierw do indywidualnego Izraelity, znajdującego się w sporze sądowym ze swoim bliźnim (31-32), następnie do całego lud, doznającego militarnych niepowodzeń (ww. 33-34), suszy (ww. 35-36), głodu i zarazy oraz innych klęsk żywiołowych (ww. 37-40). Zalicza do nich także pozycję cudzoziemca przybywającego z dalekiego kraju (ww. 41-43), a wreszcie ludu wyruszającego na wojnę i pokonanego przez nieprzyjaciela (44-45), i ostatecznie uprowadzonego na wygnanie (46-51). Do pewnego stopnia i w bardzo ogólnym zarysie ich układ zapowiada treść całego dzieła ${ }^{7}$, a zarazem zarysowuje kierunek jego interpretacji. Żadna z opisanych sytuacji nie jest rozwinięta narracyjnie, lecz odniesiona do Boga w niebie w przeciwstawieniu do świątyni i Salomona, jej budowniczego ${ }^{8}$. Żarliwy ton błagań artykułowanych przez króla z głębi egzystencjalnych potrzeb tych, którzy w przyszłości będą ich doświadczać, kontrastuje z opisem architektonicznych szczegółów zawartych w sprawozdaniu z budowy świątyni i z ilością ofiar, złożonych z okazji jej poświęcenia. Sytuacje graniczne ludu są tylko zarysowane a konstrukcja świątyni dokładnie, drobiazgowo i z upodobaniem przedstawiana. Obraz wspaniałości świątyni niespodziewanie szybko idzie w zapomnienie, gdy zaczynamy się przypatrywać sytuacjom granicznym w opowieściach prorockich.

\section{KONIEC W CYKLU ELIASZA I ELIZEUSZA 2 KRL 6,24-31}

Obok opowiadań z udziałem Eliasza (1 Krl 17), szczególnie wymowny jest epizod, będący kontynuacją kronik opisujących działania wojenne między królem Aramu i Izraelem (2 Krl 6,8-23). Rozpoczyna go krótka

${ }^{6}$ Własną typologię przedstawił K. Jaspers, wyróżniając walkę, winę, przypadek, śmierć.

7 Por. P. Leithart, $1 \& 2$ Kings, London 2006, s. 70.

${ }^{8}$ Por. M.A. Sweeney, I \& II Kings. A Commentary, Louisville, Kentucky 2007, s. $130.131-135$. 
informacja o kolejnej mobilizacji wojsk aramejskich, zarządzonej przez Ben-Hadada, który na ich czele wyruszył oblegać Samarię $(6,24)$. Nie samo oblężenie od strony strategii i użytych środków ${ }^{9}$ jest jednak treścią dalszej opowieści, lecz jego skutki. Widzimy tylko to, co dzieje się w mieście otoczonym i zamkniętym przez wojska, w którym brakuje jedzenia. Na arenę opowiadanej historii wkraczają ceny żywności. Grozę głodu nie pokazuje liczba umierających ludzi, lecz bezwzględne prawa ekonomii.

Niedostatek i wysokie ceny artykułów spożywczych to tylko jeden przejaw głodu. Bezimienny król dokonujący inspekcji murów obronnych myśli, że w oblężonym mieście, którego jest reprezentantem, nic gorszego nie może się już zdarzyć. Głód pokazuje się od innej strony, kiedy pewna kobieta zbliża się do króla, prosząc o ratunek. On jednak wie, że nie może nic zrobić, gdyż miasto nie dysponuje żadnymi zapasami $(6,26-27)^{10}$. Pyta ją więc z czym faktycznie do niego przyszła. Wtedy ona relacjonuje treść umowy, którą zawarła z nią jej sąsiadka: „Ta kobieta umówiła się ze mną: 'daj twego syna, a zjemy go dzisiaj, mojego zaś syna zjemy jutro.' Ugotowałyśmy więc mego syna i zjadłyśmy go. Mówię do niej następnego dnia: 'daj twego syna, a zjemy go', lecz ona ukryła swego syna' (6,28-29).

Król rozdziera szatę na znak pokuty, ale jego gest wygląda groteskowo wobec potworności kanibalizmu matek. Zachowania kobiet są trudne do jednoznacznej oceny, i wbrew niektórym opiniom nie można ich bezwzględnie potępićn ${ }^{11}$. Propozycja zjedzenia dziecka wychodzi od drugiej kobiety, nie od jego własnej matki. W jej słowach nie ma jednoznacznej wskazówki, czy chodzi o dziecko już martwe czy jeszcze żywe ${ }^{12}$. Jedno jest pewne, obydwie od dłuższego czasu muszą nie mieć, co jeść. Zagadkowa wydaje się postawa kobiety oskarżonej o ukrycie swego syna. Czy w duchu Pwt 28,53-57 schowała swoje martwe dziecko, żeby nie podzielić się nim ze swoją sąsiadką i żeby sama mogła w skrytości zaspokoić nim głód, czy też zrobiło się jej żal żywego syna, jak owej matce $\mathrm{z}$ procesu sądowego Salomona (1 Krl 3,26), i dlatego chce go zachować

9 Zob. P.B. Kern, Ancient Siege Warfare, Bloomington, Indiana 1999, s. $29-61$.

${ }^{10}$ S. Lasine, Jeroham and the Cannibal Mothers (2 Kings 6,24-33): Solomon's Judgment in an Inverted World, "Journal for the Study of the Old Testament" 50 (1991), s. 27.

11 Tamże, s. $41 \mathrm{n}$.

${ }_{12}$ H.S. Pyper, Judging the Wisdom of Solomon: The Two-Way Effect of Intertextuality, "Journal for the Study of the Old Testament" 59 (1993), s. 32n. 
przy życiu? Te niejednoznaczności w postępowaniu kobiet sugerują, że głód w oblężonym mieście nie jest czymś dającym się łatwo zrozumieć i ocenić na podstawie prostej ciągłości między potrzebą i zaspokojeniem ani też w ramach porządku moralnego reprezentowanego przez króla. Nie ma on zresztą wystarczających kwalifikacji etycznych umożliwiających rozstrzygnięcie przedłożonej mu sprawy.

Przebieg wydarzeń zrelacjonowany przez skarżącą się kobietę daje się jednak odtworzyć, jeśli się spojrzy na nie z perspektywy układu fabularnego zapisanego w $1 \mathrm{Krl}$ 3,16-28 oraz w Pwt 28,53-58. Pierwszy z nich rozróżnia między dobrą matką, ratującą żywe dziecko, i złą matką, domagającą się jego zabicia. Drugi definiuje kanibalizm jako spożywanie ciał martwych osób. Kiedy zmarł syn pierwszej kobiety, druga zaproponowała, żeby martwe dziecko ugotować i zjeść. Kobiety umówiły się, że kiedy umrze syn drugiej, zrobią to samo. Widocznie dziecko drugiej jeszcze nie umarło, dlatego jego matka je ukryła. Pierwsza po zjedzeniu własnego dziecka, powodowana zazdrością i poczuciem winy, zażądała od drugiej dotrzymania zawartej wcześniej umowy, co musiało prowadzić do zabicia jej żywego syna i przygotowania z niego posiłku. I ta jest złą matką. Druga z kolei, decydując się na ukrycie żywego dziecka okazuje się dobrą matką. Tym niemniej potwierdzony świadectwem pierwszej kobiety kanibalizm w stosunku do jej martwego dziecka oznacza, że doświadczenie głodu powoduje zerwanie ciągłości, które w oblężonym mieście odnosi się do wszystkich zapasów żywności. Wtedy to głodne miasto zaczyna zjadać swoje dzieci, zamykając przed sobą przyszłość, reprezentowaną przez następne pokolenia (por. Lm 4,10) ${ }^{13}$.

\section{KONIEC W NARRACYJNYM ZWIEŃCZENIU}

\subsection{KRL $24,10-17$}

Zbliżający się koniec historii pokrywa się z zakończeniem Księgi. Wprowadza doń pośpiesznie opowiadana historia ostatnich władców Judy usuwanych z urzędu najpierw przez króla egipskiego, później przez

${ }^{13}$ Por. S. Lasine, Jeroham, s. 35. 
króla babilońskiego (2 Krl 23,31-24,7). Wyznacza ona kierunek lektury, skupionej na postaci króla, w którego losach streszczono przeznaczenie całego narodu. Nie ustanawiają go teraz ani Bóg ani lud, lecz władcy Egiptu lub Babilonii. Tak więc Juda i Jerozolima stają się w mocnym sensie tego słowa częścią historii imperialnej, w której jedyną siłą sprawczą jest władca imperium.

W stosunkowo obszernej relacji jedynym protagonistą pojawiającym się na scenie jest Nabuchodonozor. Wszystkie wydarzenia w niej zawarte mają związek z jego przybyciem (ww. 10-11) i obecnością (ww. 12-17). W krótkiej wzmiance z rozpoczęcia i trwania oblężenia Jerozolimy dominuje i jakby unosi się nad całym miastem wypunktowana czterokrotnie postać króla babilońskiego, przedstawiona za pomocą długiej frazy $\mathrm{z}$ imieniem, tytułem i nazwą imperium (2 Krl 24,10-12). Przybywając pod Jerozolimę, Nabuchodonozor ukazuje się jednoosobowym reprezentantem Babilonu i jego pełnym wcieleniem $(24,11)$.

Z oblężonego miasta do króla Babilonu wychodzi młody, osiemnastoletni król Judy i królowa matka. Wraz z nim pojawiają się jego dworzanie, dowódcy i urzędnicy, słowem wszyscy reprezentujący rządzącą elitę kraju. Poddanie się to jego ostatni akt jako podmiotu historii. Natychmiast bierze go do niewoli król babiloński, który kapitulację zapisuje na konto własnych osiągnięć jako fakt zaistniały w ósmym roku swoich rządów ${ }^{14}$. Tym samym historia Judy w wymiarze własnej ciągłości chronologicznej zostaje przerwana, a w jej miejsce wkracza historia imperialna. Nie otrzymujemy więc wglądu w codzienne życie dziejące się w Jerozolimie. Przestrzeń wokół niej wypełnia całkowicie ciało króla babilońskiego. Przez metonimiczny zabieg to nie żołnierze, lecz on sam ją plądruje, wynosząc zgromadzone $\mathrm{w}$ niej skarby. Jego działania zestawiono $\mathrm{z}$ dokonaniami Salomona, króla Izraela. Wykonane przez tego ostatniego złote dekoracje - znak wielkości i wspaniałości świątyni PANA oraz jego królestwa, stają się łupem władcy babilońskiego (w. 13, por. $1 \mathrm{Krl} \mathrm{9,1-9).} \mathrm{To,} \mathrm{co} \mathrm{Salomon}$ skonstruowat, Nabuchodonozor dekonstruuje.

14 Także Kroniki Królów Babilońskich odnotowują zdobycie Jerozolimy i usunięcie króla Judy w 7 roku panowania Nabuchodonozora, por. M.A. Sweeney, I \& II Kings , s. 458-459. Por. także J. Weinberg, The Babylonian Conquest of Judah: Some Addictional Remaks to a Scientific Consensus, "Zeitschrift für die alttestamentliche Wissenschaft" 118 (2006), s. 597-610. 
Proces dekonstrukcji całego okresu panowania królów zaznaczono pięciokrotnym użyciem terminu wygnać/wygnanie. Postaci dotąd niewidoczne, ukryte za murami wyłaniają się teraz w kolumnie osób, spisanych na listach przesiedlonych. Rozmieszczono je w trzech odsłonach (ww. 14-16). Rytm pierwszej nadaje czterokrotnie zastosowana partykuła $k o ̄ l$ w odniesieniu do deportowanych: wszyscy mieszkańcy Jerozolimy, wszyscy urzędnicy, wszyscy żołnierze (w liczbie 10 tysięcy), wszyscy rzemieślnicy i kowale. Ukazując Nabuchodonozora jako skazującego na wygnanie całe miasto, całą jego społeczno-polityczną elitę, tworzy ona nieodparte wrażenie, że pozostawia on je pustym ${ }^{15}$. W drugiej odsłonie na scenę wkracza procesja wygnańców: król, jego matka, żony i związani z nim wybitni obywatele. Mają oni teraz status jeńców. Deportując ich z Jerozolimy do Babilonu, Nabuchodonozor dokonuje zerwania historycznej ciągłości następstwa tronu. Jojakin jest za młody, żeby mieć syna, który mógłby po nim objąć rządy (Jr 22,30), a jeśli nawet miałby jakiegoś, to nie pojawia się on na scenie. Jego władza dochodzi do kresu w kolejnym akcie, w którym znowu zostaje przedłożona lista deportowanych. Tym razem zawiera ona cały militarny personel, stanowiący o sile obronnej państwa. Wiersze 14-16 zorganizowane są wokół czasowników, których jedynym podmiotem jest Nabuchodonozor: on i tylko on skazuje na wygnanie (w. 14), dokonuje przesiedlenia (w. 15), i wreszcie przyprowadza wygnańców do Babilonu (w. 16). Zarządza całą przestrzenią rozciągającą się od bram Jerozolimy (w. 11) do wrót stolicy imperium (w. 16.), będąc jedyną siłą sprawczą oblężenia i deportacji. Kiedy sadza na tronie Judy Mattatiasza, zmieniając jego imię na Sedecjasz (w. 17), okazuje się również rzeczywistym sprawcą historii, ustalając jej czasową konfigurację. Mattatiasz jest bowiem kolejnym synem Jozjasza, a więc wujem deportowanego Jojakina, który wraz z imieniem pominiętym w formule następstwa tronu, znika $\mathrm{z}$ areny działań historycznych. Jest to cofnięcie się $\mathrm{w}$ przeszłość, a nie kolejny krok w przyszłość w łańcuchu sukcesji. Podporządkowanie Sedecjasza i jego królestwa władcy Babilonu oznacza dokonanie w niej

15 Ikonografia asyryjska upamiętniająca zwycięskie wojny królów Asyrii przedstawia zdobyte miasta jako puste, por. M.G. Hasel, Assyrian Military Practices and Deuteronomy's Laws of Warfare, w: Writing and Reading War. Rhetoric, Gender, and Ethics in Biblical and Modern Context, eds. B.E. Kelle, F.R. Ames, Atlanta 2008, s. 76. 
czasowej wyrwy. Historia polityczna imperium babilońskiego i królestwa Izraela/Judy łączy się $\mathrm{w}$ konfrontacyjnym napięciu $\mathrm{z}$ historią religijną, skupioną wokół centrum jakim była świątynia Salomona. Król babiloński zamyka tę historię klamrą, spinając jej tragiczny koniec z pełnym splendoru początkiem, teraz całkowicie zeń odartym.

\subsection{KRL $24,18-25,7$}

Historia Judy nie trwa dalej, dalej trwa jej koniec. Podkreśla to sposób przedstawienia panowania Sedecjasza ${ }^{16}$. Zastosowano tu formuły typowe dla opisu wstąpienia na tron ostatnich królów Judy. Są one uderzająco podobne do wprowadzeń do rządów królów Izraela, zakończonych deportacją asyryjską $(2 \mathrm{Krl} 17,1-6)^{17}$. Juda więc znajduje się na tej samej drodze, co Izrael, i nieodwołalnie zmierza ku swemu upadkowi. $\mathrm{Z}$ jedenastu lat panowania Sedecjasza pominięto dziewięć, jakby w nich nic istotnego się nie wydarzyło. Zarejestrowano tylko jego bunt przeciw królowi Babilonu $(2 \mathrm{Krl} 24,20)^{18}$. Jako pierwszą ważną datę w kronice jego rządów zapisano więc dopiero dzień przybycia Nabuchodonozora i jego armii. ${ }^{19}$ Architekturę przestrzeni tworzą dwa fakty: założenie obozu wojsk babilońskich pod Jerozolimą i budowa wałów oblężniczych wokół miasta. Te ostatnie uwypuklają moment oblężenia ${ }^{20}$, a zarazem odzwierciedlają przejęcie historiograficznego stylu imperialnej kroniki wojennej z jej ideologicznym punktem widzenia. Jerozolimę postrzega się z zewnątrz, z pozycji zajmowanej przez wojska babilońskie ${ }^{21}$.

16 Początek podobny jest do innych przedstawień, ale brak w nim standardowego zakończenia $\mathrm{z}$ opisem śmierci i wprowadzeniem następcy tronu, M.A. Sweeney, $I$ \& II Kings , s. 462.

17 Tamże, s. 458.

18 Zob. obszerne relacje z czasów Sedecjasza w Księdze Jeremiasza: 32,1-5; 34,1-22; 37-39. Według J. Pakkala (Zedekiah's Fate and the Dynastic Succession, „Journal of Biblical Literature" 125 (2006), s. 443-452) dwa pierwsze fragmenty zdają się przeczyć opisowi w 2 Krl 24,18-25,7. Prorok zapowiada w nich, że Sedecjasz umrze w Babilonie w pokoju (Jr 34,5) i będzie miał pogrzeb z królewskimi honorami.

19 R.L. Cohn, 2 Kings. Berit Olam: Studies in Hebrew Narrative and Poetry, Collegeville, Minnesota 2000, s. 168.

${ }^{20}$ Por. P.B. Kern, Ancient Siege Warfare, Bloomington 1999, s. 9-21.29nn.

${ }^{21}$ R.L. Cohn, 2 Kings, s. 168. 
Ta optyka szybko się jednak zmienia. W wierszu 2 miasto widziane jest już od wewnątrz ${ }^{22}$. Na chwilę przestaje być jedynie przedmiotem ataku Babilończyków, a staje się podmiotem, nie tyle jednak działającym, ile doznającym. Dla ludzi zamkniętych w mieście istotną rolę odgrywa czas. Oblężenie trwa aż do jedenastego roku rządów Sedecjasza, czyli od roku do dwóch lat. Na pierwszy plan wysuwa się głód, osiągający swoje apogeum w dziewiątym dniu miesiąca. Niesprecyzowana data może wskazywać na pierwszy miesiąc ostatniego roku panowania Sedecjasza ${ }^{23}$. Ale może być także świadomym zabiegiem retorycznym. W tej czasowej sekwencji wyróżniają się dwa pamiętne momenty: dokładnie określony początek oblężenia (w. 1) i nieokreślony koniec (jakby koniec miał trwać i nic po nim nie miało nastąpić), związany z kulminacją głodu (ww. 2-3). Pomiędzy nimi nie zapisano żadnych szczegółowych informacji, choć lukę tę można wypełnić, odwołując się do wcześniejszych relacji z oblężenia Samarii (2 Krl 6,24-31) i Jerozolimy (2 Krl 18,27). Ich brak zatem na płaszczyźnie narracji musi odzwierciedlać zerwanie czasowej ciągłości $\mathrm{w}$ historii miasta.

Jeszcze głębsze cięcie wprowadzają wiersze $4-7^{24}$. Zestawiają podwójny ruch. Pierwszy, zasygnalizowany zrobieniem wyłomu w murach obronnych, podpowiada, że żołnierze babilońscy, choć jeszcze niewidoczni, za chwilę wkroczą do miasta. Drugi, w przeciwną stronę, przedstawia obrońców na drodze $z$ miasta. Noc, podczas której decydują się na ucieczkę, nie jest wyłącznie detalem kronikarskiej rzetelności, lecz zyskuje prawdziwie symboliczne znaczenie. Od tego momentu bowiem rozpoczyna się noc końca. Nożyce dokonujące cięcia będą się rozwierać coraz bardziej w kolejnych odsłonach. Żołnierze zamiast do ostatka bronić miasta, wszyscy opuszczają je pod osłoną ciemności, żeby ratować swoje życie. Kiedy w pościg rusza wojsko babilońskie, okazuje się, że ściga ono króla judzkiego, dotąd niewidocznego. Oblężenie i głód wymazały jego obecność z historii miasta, niewidoczny jest też lud, będący przedmiotem władzy królewskiej. Król zatem staje się całkowicie zbędny. Zjawia się

22 Tamże.

${ }^{23}$ Tak M.A. Sweeney, I \& II Kings, s. 463.

${ }_{24}$ Por. P.R. House, 1, 2 Kings (The New American Commentary, vol. 8), Nashville 1995, s. 397. 
dopiero na stepach Jerycha, ale sam, bez swojej armii, idącej w rozsypkę (w. 5). Dekonstrukcja instytucji króla i jego królestwa, nie tylko w sferze fizycznej, lecz także symbolicznej, w kolejnej odsłonie staje się jeszcze bardziej wymowna. Pochwycony i przyprowadzony do władcy babilońskiego otrzymuje wyrok skazujący, wykonany w trybie natychmiastowym (w. 6). Rytm zdarzeń ulega gwałtownemu przyspieszeniu: oskarżenie, wyrok i kara kumulują się w jednym epizodzie o skondensowanej treści. Najpierw na oczach króla zostają straceni jego synowie, jeszcze bardzo młodzi, gdyż Sedecjasz liczy co najwyżej 32 lata (por. $2 \mathrm{Krl}$ 24,18). Żaden z nich nie zasiądzie na tronie swego ojca. Ciągłość królestwa zostaje przerwana jednoznacznie i ostatecznie. Te same oczy, które oglądały okrutną śmierć swoich następców, zostają wyłupione. W symbolicznym okaleczeniu przypominającym tragiczny los Edypa objawia się fundamentalna prawda biblijnej historiografii, że instytucja króla w odniesieniu do swej podstawowej funkcji przewodzenia ludowi, od samego początku była całkowicie ślepa i dopiero teraz na końcu okazuje się chybionym projektem. Sedecjasz żyje, lecz nie jako król. Uprowadzony do Babilonu, ślepy i w łańcuchach nigdy już nie powróci na scenę historii (w. 7). Jerozolima pozostanie odtąd miastem bez króla, jego dworu $i$ wojska. Chronologia wydarzeń liczona według lat panowania królów Judy przestaje obowiązywać. Czas będzie liczony według innego kalendarza, który niesie z sobą odmienną pod względem kulturowym organizację zdarzeń.

\section{3. $2 \mathrm{KRL} 25,8-21$}

Na scenie pojawia się kalendarz babiloński. Siódmego dnia piątego miesiąca, w dziewiętnastym roku panowania Nabuchodonozora, dowódca jego straży przybocznej, Nebuzaradan wkracza do Jerozolimy i rozpoczyna dzieło zburzenia (w. 8). Zanim Jerozolima stanie się łupem oblegających ją żołnierzy, Nabuchodonozor narzuca Judejczykom na ich ziemi porządek czasowy Babilonu ${ }^{25}$. Moment przesiedlenia będzie liczony latami rządów królów babilońskich. Odtąd Judejczycy wygnani z własnej ziemi, żyć będą bardziej w czasie niż w przestrzeni. Ich dzieje staną się najpierw częścią

${ }^{25}$ Por. R.L. Cohn, 2 Kings, s. 169. 
historii imperialnej zanim ich terytorium zostanie umieszczone w nowej konfiguracji geograficznej w obrębie granic imperium.

Przejście od jednego kalendarza do drugiego nie dokonuje się ręką historyka i nie polega na umieszczeniu nowej daty w kronice. Odbywa się raczej w procesie materialnego zniszczenia miasta. Cała aktywność Nebuzaradana, jedynego działającego podmiotu, polega na spaleniu wszystkich domów. Termin 'dom' użyto tutaj czterokrotnie. Zgodnie z sekwencją przedsięwzięć budowlanych Salomona (1 Krl 6-7), wojsko chaldejskie spaliło najpierw dom PANA, potem dom króla, następnie wszystkie domy Jerozolimy, wreszcie każdy ważniejszy dom. Spalenie ogniem wszystkich budowli sugeruje działanie mające na celu całkowite zniszczenie. W ten sposób, z krajobrazu miasta zostają wymazane wszystkie miejsca nadające się do zamieszkania, zarówno mieszkanie Boga jak i mieszkania Jego ludu.

Miasto, to miasto nie jest już potrzebne, gdyż nie ma nikogo, kto mógłby w nim zamieszkać. Nebuzaradan bowiem uprowadził na wygnanie nie tylko pozostałą w nim resztę ludu, ale także zbiegów, którzy wcześniej przeszli na stronę króla babilońskiego ${ }^{26}$ oraz resztę pospolitego tłumu, czyli wszystkich, mogących w przyszłości podjąć się jego odbudowy (w. 11). Listę przesiedlonych przerywa na moment wzmianka o pozostawieniu najbiedniejszej ludności wiejskiej, przeznaczonej do pracy w polu i winnicach, a więc poza miastem (w. 12). Kontynuuje ją inna lista - przedmiotów stanowiących wyposażenie świątyni (ww. 13-17). Figurują na niej te, które występują w sprawozdaniu z jej budowy w $1 \mathrm{Krl}$ 7,15-50. Na pierwszy plan wysuwają się dwie kolumny. Ich opis dominuje nad całą listą, gdyż pojawia się na początku (w. 13) i na końcu (ww. 16-17). Babilończycy nie interesują się ich symbolicznym znaczeniem, zawartym w nazwach Jakin i Boaz, które podkreślały, że to JHWH ustanowił Izraela, a jego

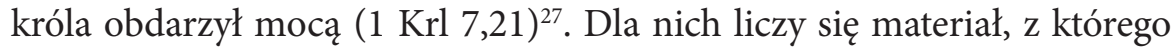
kolumny jak również inne sprzęty przeznaczone do służby Bożej zostały wykonane (w. 14). Chodzi o brąz, wymieniony tutaj siedmiokrotnie. Przedmioty ze złota i srebra wspomniane są tylko mimochodem. Ta nie dająca się zważyć ilość brązu w całości zostaje zabrana do Babilonu. $\mathrm{W}$ procesie materialnego zniszczenia zostaje usunięta cała symboliczna

${ }^{26}$ Zob. J. Weinberg, The Babylonian, s. 602.

27 Por. J.C. Long, 1 \& 2 Kings, (NIV Commentary series), Joplin 2002, s. 536. 
przestrzeń świątyni. Będzie o niej przypominać jedynie wygląd kolumn, z ich wysokością i ornamentem oplatającym głowice (w. 17). Stopione na brąz prawdopodobnie potrzebny dla celów wojskowych, nie będą jej materialną pamiątką. Będzie nią wyłącznie opis zachowany na piśmie.

Ostatni epizod składa się z imion osób, pełniących specyficzne urzędy w królestwie (ww. 18-21) ${ }^{28}$. Najpierw pojmano najwyższego kapłana, jego zastępcę i trzech stróżów progów, później, ukrywających się dowódców wojskowych, doradców króla oraz przedstawicieli prowincji. Zaprowadzono ich wszystkich do króla babilońskiego w Ribla i tam z jego rozkazu zabito. Śmierć kapłanów powoduje zaprzestanie składania ofiar i wszystkich religijnych funkcji spełnianych przez świątynię. Stracenie odnalezionych urzędników króla i znaczących postaci spośród właścicieli ziemskich podkreśla ostateczny kres instytucji monarchii. Wymienione osoby nie zostały deportowane do Babilonu, lecz zamordowane w Ribla. $\mathrm{W}$ ten sposób, Juda został pozbawiony ludzi, stanowiących polityczną i społeczną elitę narodu, mogących w przyszłości odegrać rolę przywódców. Podsumowujące stwierdzenie: „Juda został wygnany ze swojej własnej ziemi” (w. 21) wraz z $2 \mathrm{Krl}$ 24,20, wprowadzającym motyw gniewu PANA, odrzucającego Jerozolimę i Judę od swego oblicza, stanowi klamrę zamykającą wydarzenia końca ${ }^{29}$.

Nieoczekiwanie, opowiadana historia trwa jednak dalej. W ziemi Judy zamieszkuje jeszcze jakaś reszta ludu, którą pozostawił Nabuchodonozor, król babiloński, a zarządcą nad nimi ustanowił Godoliasza, rezydującego nie w Jerozolimie, lecz w Mispie, nowym, wyznaczonym przez Babilończyków, centrum administracyjnym. Jako syn Achikama i wnuk Szafana, urzędników królewskich z czasów króla Jozjasza, a zarazem przedstawiciel stronnictwa pro-babilońskiego ${ }^{30}$, posiadał on wystarczające

${ }^{28}$ Por. R.L. Cohn, 2 Kings, s. 170.

29 Tamże.

${ }^{30}$ Należał do niego również prorok Jeremiasz, oskarżany przez obóz patriotyczny, proegipski, o zdradę stanu, por. Jr 37,11-16, por. M.A. Sweeney, I \& II Kings, s. 469. 
kompetencje, aby na nowo zorganizować życie na ziemiach opanowanych przez wojska babilońskie. Jednak grupa ocalonych dowódców wraz ze swymi żołnierzami zamiast, zgodnie z przysięgą złożoną im przez Godoliasza, uznać władzę króla babilońskiego i włączyć się w projekt odbudowy, kontynuuje postawę buntu, doprowadzając sytuację w Judzie do definitywnej i nieodwołalnej klęski. Izmael pochodzący z rodu królewskiego, mordując Godoliasza i stacjonujących z nim w Mispa Chaldejczyków, zmusił całą pozostałą resztę do ucieczki. Ze strachu przed odwetem Babilończyków, wszyscy od najmłodszego do najstarszego przybyli do Egiptu, pozostawiając za sobą tylko zgliszcza i całkowicie opustoszały kraj. Ostatecznego zniszczenia dopełnili więc nie Babilończycy, lecz pozostali w kraju Judejczycy. Nie można mocniej wyrazić strategii zaślepienia i samozniszczenia działającej w historii Izraela i Judy.

Relacja zamieszczona w Księgach Królewskich rozpoczyna się od budowy monumentalnej świątyni Salomona, 480 lat od wyjścia Izraelitów z Egiptu (1 Krl 6,1), a kończy się powrotem ocalałej reszty do miejsca, z którego zostali wyprowadzeni ich przodkowie. Wówczas wychodzili pod wodzą Mojżesza i Aarona, teraz wracają do Egiptu, nie mając żadnego przywódcy. To koniec zamykający całą historię. Dzieje Izraela zatoczyły więc koło w mocnym historiograficznym sensie: historia doszła do punktu, w którym się rozpoczęła, wymazując go zarazem, gdyż wśród przebywających w Egipcie nie ma nikogo na miarę Mojżesza. Jaką więc wymowę mają ostatnie zdania, tworzące jej zaskakujący epilog (2 Krl 25,27-30)? Czy przedstawiają zdarzenia, usiłujące podjąć przerwane na moment dzieje i dać impuls do ich przyszłej kontynuacji, czy przeciwnie, potwierdzają definitywne zamknięcie, które nakłada się na początek? ${ }^{31}$

Ten rodzaj otwartego zakończenia sugeruje, że katastrofa babilońska w hermeneutycznej perspektywie Ksiąg Królewskich wyczerpuje cały sens opowiedzianej w nich historii. Żadne następne zdarzenie nie okazało się na tyle inne jakościowo, żeby mogło dodać do niej jakieś nowe znaczenie warte opowiedzenia. Dlatego w kanonie Biblii Hebrajskiej Księgi

${ }^{31}$ Jak potoczyły się losy tych dwóch przeciwstawnych interpretacji relacjonuje m. in. D.F. Murray, Of All The Years The Hopes - Or Fears? Jehoiachin In Babylon (2 Kings 25:27-30), „Journal of Biblical Literature” 120 (2001), s. 245-265; por. także R.D. Nelson, First and Second Kings. Interpretation, a Bible Commentary for Teaching and Preaching, Louisville 1987, s. 265-269. 
Ezdrasza i Nehemiasza, opisujące powrót z wygnania, nie kontynuują Ksiąg Królewskiej, lecz zostały umieszczone w zbiorze Pism, który oczywiście kończy się opisem deportacji do Babilonu w 2 Krn 36.

\section{PODSUMOWANIE}

Księgi Królewskie stanowią ostatnią część wielkiego dzieła, rozciągającego się od Księgi Rodzaju do 2 Królewskiej. Nie jest to dzieło opisujące historię ludzkości i Izraela w sensie nowożytnych przedstawień historycznych. Jest to raczej wizja świata i żyjącego w nim człowieka, oparta na historycznym doświadczeniu Izraela, a wyłoniona przede wszystkim, choć nie bez odwołań do tworzonych i zachowywanych w nim tradycji, z medytacji nad katastrofą babilońską. Oczywiście Izrael nie przeżyłby tragizmu tej katastrofy jako końca historii, i nie poddał jej pod tak głęboki namysł, gdyby doświadczenia historyczne ją poprzedzające nie wytworzyły jakiś małych punktów nieciągłości, a w nich zarysów religijnej odrębności. Hermeneutyka ciągłości w Księgach Królewskich ma charakter retrospektywnego poszukiwania punktów nieciągłości, tłumaczących koniec i wyjaśniających wcześniejsze wydarzenia $z$ jego perspektywy. Ich sens i funkcja odsłaniają ostateczne zerwanie ciągłości w odniesieniu do religii tubylczej, zdefiniowanej w prorockich konfrontacjach $\mathrm{z}$ kultem Baala i przeniesienia myślenia religijnego zakorzenionego w rolniczych rytuałach Kanaanu na myślenie diaspory w Babilonie. Biblia jest właśnie owocem myślenia diasporycznego. Religijność tubylcza podporządkowuje osobę ludzką, jej godność i życie, ziemi i związanych z nią obrzędom i zwyczajom. Dla wiary diasporycznej posiadanie ziemi jest zawsze prowizoryczne i odbywa się za pomocą częściowego spełniania obietnicy ziemi, nigdy nie zagwarantowanej raz na zawsze. Stąd wiara biblijna dystansuje się od ambicji narodowych i od ekskluzywnego nacjonalizmu, widząc w nich rodzaj bałwochwalczej ideologii religijnej, odzierającej ludzką jednostkę z jej godności i podporządkowującej ją celom i interesom ideologicznie zdefiniowanej zbiorowości. 
Streszczenie. Ze względu na swój dominujący narracyjno-retoryczny charakter Księgi Królewskie (podobnie jak pozostałe tzw. księgi historyczne ST) zostały pomyślane jako tekst a nie jako historia w dzisiejszym rozumieniu tego terminu, i jako tekst przeznaczone są do czytania w taki sposób, aby ujawniały one swoją siłę oddziaływania na czytelników, a nie odsyłały ich do jakiejś hipotetycznie zrekonstruowanej przeszłości. W hermeneutyce końca historii, którego narracyjne opisy znajdują się w kluczowych momentach struktury literackiej, wybrzmiewa pytanie, cofające się poprzez układ fabularny aż do początku: jakie wydarzenia uruchomiły łańcuch przyczynowo-skutkowy, którego zwieńczeniem okazał się ów koniec?' Specyficzny rodzaj narracji historycznej Ksiąg Królewskich pokazuje klęskę projektu stworzenia wspólnoty religijnej o prerogatywach politycznych, czyli utożsamienia religii z instytucjami politycznymi, co obowiązywało w kulturze narodów starożytnego Bliskiego Wschodu. Żydom po klęsce babilońskiej nigdy nie udało się (choć próbowali) stworzyć politycznych ram dla swojej wiary. Pozostali wspólnotą religijną oddzieloną od struktur politycznych, a więc wspólnotą o naturze diaspory.

Słowa kluczowe: wojna; głód; nieciągłość; religijność tubylcza; religijność diaspory.

Abstract. End of History as a Hermeneutic Perspective in the Book of Kings. Because of its narrative-rhetorical character the Book of Kings is composed not as a history in modern sense, but as a text to read in such a way as to manifest its power to make deep impact on its readers. The hermeneutics of the end of history puts the question, what kind of events launch cause-effect chain which culminates in this end. Applied to the Book of Kings it shows a failure of a project to create a religious community in terms of political institution of monarchy. After the Babylonian exile Jewish religion has turned out to be separated from any political framework. In its narrative shape it moved from a vernacular religion into the specific religion of diaspora.

Keywords: war; famine; discontinuity; indigenous religion; diaspora religion.

\section{BIBLIOGRAFlA}

Cohn R.L., 2 Kings. Berit Olam: Studies in Hebrew Narrative and Poetry, Collegeville, Minnesota 2000

Exum Ch., Tragedy and Biblical Narrative: Arrows of the Almighty, Cambridge 1996

Hasel M.G., Assyrian Military Practices and Deuteronomy's Laws of Warfare, w: B.E. Kelle, F.R. Ames (eds), Writing and Reading War. Rhetoric, Gender, and Ethics in Biblical and Modern Context, Atlanta 2008, s. 67-81

House P R., 1, 2 Kings. The New American Commentary, vol. 8, Nashville 1995 
Jaspers K., Sytuacje graniczne, tłum. A Staniewska, M. Skwieciński, w: Jaspers, red. R. Rudziński, Warszawa 1978

Kern P.B., Ancient Siege Warfare, Bloomington, Indiana 1999

Lasine S., Jeroham and the Cannibal Mothers (2 Kings 6,24-33): Solomon's Judgment in an Inverted World, JSOT 50 (1991), s. 27-53

Leithart P., $1 \nLeftarrow 2$ Kings, London 2006

Long J.C., 1 \& 2 Kings, College Press NIV Commentary series, Joplin 2002

Murray D.F., Of All The Years The Hopes - Or Fears? Jehoiachin In Babylon (2 Kings 25:27-30), JBL 120 (2001), s. 245-265

Nelson R.D., First and Second Kings. Interpretation, a Bible Commentary for Teaching and Preaching, Louisville 1987

Pakkala J., Zedekiah's Fate and the Dynastic Succession, JBL 125 (2006), s. 443-452

Pyper H.S., Judging the Wisdom of Solomon: The Two-Way Effect of Intertextuality, JSOT 59 (1993), 25-36.

Sweeney M.A., I \& II Kings. A Commentary, Louisville, Kentucky 2007

Weinberg J., The Babylonian Conquest of Judah: Some Addictional Remaks to a Scientific Consensus, ZAW 118 (2006), s. 597-610 (DOI 10.1515/ZAW.2006.032)

Yerushalmi Y.H., Zakhor. Jewish History and Jewish Memory, Seatle 1982, 1996. 